\title{
Dialog om sättet att sluta stycken
}

\author{
Cecilia Davidsson och Tommy Olofsson
}

\section{En litterär övning}

Vintern 2014/15 genomförde vi ett experiment inom våra kurser i kreativt skrivande vid Linnéuniversitetet. Involverade i detta experiment var två lärare och 60 studenter i ämnet, fördelade på A-, B- och D-nivå. Den övningsuppgift vi lärare gav studenterna var att skriva slutet på en nyskriven novell av Cecilia Davidsson, ”Vad är det som säger att du inte redan älskar mig”, som i bearbetat skick så småningom kom att ingå i novellsamlingen Höga berg, djupa dalar, utgiven i augusti 2015 av Albert Bonniers Förlag.

Vad vi undanhöll våra studenter var själva slutet på novellen, exakt 1202 tecken inklusive mellanslag, men allt det föregående, 6775 tecken, fick de läsa och använda som incitament till egna avslutningar, gjorda efter eget huvud men ändå med direkt anknytning till den förlaga som förelagts dem i form av en oavslutad berättelse.

Här infogas nu Cecilia Davidssons novell. Lägg märke till den streckade linjen i slutet av texten! Det var där vi klippte av Cecilias text, så att studenterna inte fick se hennes slut förrän de själva hade skrivit ett eget slut på historien:

\section{Vad är det som säger att du inte redan älskar mig}

En Metro satt klämd i porten och tre våningar upp stod ett fönster på vid gavel, ut strömmade en låt av Tomas Ledin - blå, blå vindar och vatten - och även dörren till lägenheten var öppen, det var bara att kliva på, mitt i natten.

Vem vet, tänkte hon.

Hallen var tom - tömd - sånär på en matta som låg hoprullad mot ena väggen. På samma vägg hängde en tavla med en solnedgång i bjärta färger. Lyssna till sommarnattens sång ... Hon fortsatte in i vardagsrummet där musiken hade sin källa, förväntade sig att få se det som möjligtvis blivit kvar av festen; ett par, stillsamt vaggande på golvet med huvudena tätt ihop, förenade i en kyss. Men inget sådant. Bara en rymlig herrsko strandad mitt på parketten. Låten tog slut och det kom ingen ny. I den påföljande tystnaden kunde hon uppfatta andra ljud och hon följde dessa, inga röster, bara ljud från någon form av stillsam aktivitet, via en smal korridor som utmynnade i ett litet kök mot gården och där: en man med fingrarna i munnen.

Mannen hukade över en tallrik med överbliven plockmat från fat och skålar som belamrade diskbänken och köksbordet jämte skvättfyllda flaskor och kladdiga glas. På väggarna fler tavlor med nedåtgående solar som färgade himlarna overkligt röda.

"Hej”, sa hon.

Han höjde blicken, visade ingen förvåning, visade ingenting, medan han stoppade en salamiskiva i den redan välfyllda munnen. Han hade mörkt hår, bakåtstruket, och marinblå skjorta, finlemmade händer som blänkte av fett. Han tuggade mekaniskt med öppen mun medan han såg ut att begrunda något. Så sa han: 
”En oliv, kanske?”

Hon satte sig på stolen mitt emot, kände hur stel hon var, hon hade gått länge, utan att låta benen vila.

Ja, kanske, tänkte hon och snappade åt sig en oliv ur en avlång glasskål och sög in den mellan läpparna. Den kändes uppvärmd och var helt utan spänst.

I takt med att mannens intresse för henne ökade tuggade han allt långsammare.

”Vet du om att du är väldigt lik Tessy T?” sa han till slut.

Hon ryckte på axlarna.

"Väldigt lik faktiskt trots att du är brunett. Tessy T är mycket ljusare. Ingen fullblodsblondin, men ljus."

Han fyllde på med en blek och droppande kronärtskocka, torkade av munnen med handryggen.

"Samtidigt är ni som natt och dag. Ja, du förstår vad jag menar."

"Nej, vad menar du", sa hon och sträckte sig efter en vinglas med rött grums i botten och fyllde det till hälften med vad som stod närmast: campari.

”Du är ju inte hon menar jag, men med rätt styling skulle du kunna uppträda som hon och tjäna pengar på det. Som Elviskopiorna, det har ju blivit en industri i miljardklassen det där, och i ditt fall skulle det vara mer äkta eftersom ni lever båda två, du och Tessy T, medan Elvis är död sen länge och alla vet att kopiorna bara är kopior.”

Han gjorde en paus.

”Hon har väl inte dött nyligen, Tessy T?”

"Inte vad jag vet”, sa hon.

”Nej, det är klart att hon lever. Om hon inte ligger och dör just nu, på nåt lyxhotell, det vet vi inget om. Men you bet att vi skulle få veta i morgon.”

"Antagligen."

”Om du var Tessy T skulle jag ... Ja, vad fan skulle man göra? Jag menar, tänk om man satt här mitt i natten och så plötsligt kommer hon in i köket ... Ett sånt läge får man inte sabba. Tro inte att jag är så dum att jag inte fattar att hon är människa hon med, hon både äter och skiter som vi andra, men visst är hon nåt mer än en ätande och skitande människa - en dröm, en jävligt sexig dröm.”

Hans blick irrade runt några sekunder någonstans mitt på henne.

”Ja du”, sa han sen och petade ut något som fastnat i tänderna, något litet och rosafärgat, och knäppte i väg det med fingrarna.

”Du skulle inte göra det du nyss gjorde om hon var här”, sa hon.

"Va?"

"Du skulle inte grisa dig."

Han skrattade.

”Riktigt! Men nu är ju inte Tessy T här så jag grisar mig bäst fan jag vill.”

"Och om hon var här?"

”Ja, då skulle jag koppla på stora charmen ... Nä, sånt har hon säkert nog av: charmörer och rövslickare. Jag tror hon skulle uppskatta en helt vanlig hygglig kille som bjuder på en kopp te. Har du sett Notting Hill?”

"Men helst av allt skulle du vilja knulla henne."

"Riktigt! Men en kopp te duger också. Vi snackar ju Tessy T.”

Han sköt undan tallriken, synade henne oförblommerat i ansiktet.

"Alltså om du ... Nej."

”Jo, säg."

"Put a smile on your face. Det är allt jag vill säga."

Hon skevade med munnen, och han tog detta som ett försök från hennes sida att leverera det där eftertraktade leendet. 
"Din stackare", sa han.

Din stackare. Hon lät orden vältra runt i kroppen.

"Jag vet vad som kan få dig att le!”

Med ens så ivrig, på det där oövervinneliga sättet. Hon kände igen det. När hon var yngre hade det varit näst intill livsviktigt för vissa män att få henne att le. Genom smicker, en rolig historia, lite killkill i midjan, eller en ren order: Le för helvete!

"Du behöver inte ..."

Han reste sig upp och han var verkligen så lång som hon hade föreställt sig, säkert över en och nittio. Skulle han dra ner gylfen nu och dra fram något i hästväg så att hon skulle börja skratta av lycka?

Nej. Han fiskade upp en välanvänd servett från bordet och torkade av sig om händerna och försvann ut från köket. Vem vet, tänkte hon, och tömde glaset med den rumsvarma camparin. Sekunden efter var den långe mannen tillbaka. Han hade något vitt och ulligt i famnen: en sovande hundvalp, inte större än hennes ena fot.

"Pudeln Pär”, sa han och la valpen i hennes knä. Hon fångade upp den i händerna, kände hur varm den var.

"Söt, va?"

När valpen började gny fick hon lust att gråta.

"Du är ju för fan hopplös."

"Jag tror att den gärna skulle vilja fortsätta sova."

"Du kan få den om du vill."

”Jag är ingen hundmänniska."

"Det ante mig."

Han lyfte upp valpen i nackskinnet och gick i väg. Kom visslande tillbaka, satte sig igen och studerade skålarna framför sig innan han bestämde sig för ytterligare en kronärtskocka.

”Vem är du, förresten? Vem känner du?” frågade han medan han tuggade.

"Anna, det var hon som tipsade mig."

"Visst. Anna. Alla känner Anna."

Du och jag, tänkte hon prövande, du och jag. Varför inte? Vad är det som säger att du och jag inte kan komma att älska varandra? Vad är det som säger att du inte redan älskar mig?

Han vred lite på sig, som för att bli kvitt ett obehag. Musklerna såg hårda ut under skjortan. Det stack upp lite svart hår vid kragen. Slät hals, perfekta öron.

"När du ser på mig så där ... Du påminner om nån.”

"Tessy T?"

"Äh, jag fattar inte var jag fick det där ifrån."

Han sträckte sig bakåt i stolen, tog sig om magen. Mättnaden hade kommit som en obehaglig överraskning.

"Fy fan", sa han och gäspade.

Hon stirrade in i hans blottade gap. Min älskade. Han avbröt sin gäspning, som om han plötsligt fătt in en fluga i munnen. Han var verkligen mottaglig, men inte på det sätt hon önskade.

"Ska du inte gå hem nu”, sa han. ”Festen är slut, om man säger så.”

”Jo, det ska jag”, sa hon och reste sig från stolen och drog bort något som fastnat på undersidan av låret, en plastpåse.

God natt, min älskling.

"Ciao", sa hon. 
Han iddes inte svara, nickade bara. Hade fullt upp med matsmältningen. Och hon som inte var Tessy T lämnade köket efter att ha stoppat ytterligare en oliv i munnen. Inte för att hon var sugen på en oliv utan för att ha något att göra med tungan. Hon blev stående i hallen. Såg sig omkring medan hon gnagde och sög olivkärnan ren från kött. Ingen spegel. Det var lite konstigt. Så spände hon läpparna och sköt ut kärnan rakt i solnedgången. Det small till.

”Aj! Vad fan sysslar du med!” ropade han från köket.

Hon gick fram till tavlan och studerade hålet, som kanske alltid hade funnits där, hur skulle hon kunna veta, och stoppade dit pekfingret, borrade sig in. Han stönade högljutt. Försiktigt drog hon ut fingret. Hon hörde honom flämta, som efter en oväntad kraftansträngning. Hon såg nu att solen på tavlan snarare var på väg upp än ner, och i gryningsljuset blev allt så förtvivlat tydligt samtidigt som det fanns saker som bara försvann, suddades ut, och var mycket svåra, näst intill omöjliga, att i efterhand ens kunna föreställa sig.

Lägg alltså märke till den streckade linjen här ovan, det ställe där vi klippte av novellen, så att studenterna inte fick se det slut som författaren hade utformat. Deras uppgift blev att skriva ett eget slut, omfattande minst 1000 tecken och maximalt 1800. 60 studenter fullgjorde uppgiften, som hade tre etapper, vilka vi i vår instruktion beskrev på följande sätt:

1. Ni ska skriva slutet på den ofullständigt återgivna novell som här bifogas, ett slut som omfångsmässigt ska innefatta minst 1000 och maximalt 1800 tecken inklusive mellanslag, alltså mindre än en sida. Novellen är skriven av en etablerad författare. Vi har klippt bort slutet. Er uppgift är att skriva ett eget slut. Ni ska naturligtvis följa den dialogteknik som redan är knäsatt i berättelsen. Vi vill att ni lägger manken till för att göra så bra ifrån er som möjligt. I samband med inlämningen av ert eget slut på historien ska ni också gissa om författaren till den givna novellen är man eller kvinna samt kortfattat förklara de skäl varpå ni grundar er gissning.

2. Efter att ha fullgjort övningen kommer ni att få se hela den novell som den etablerade författaren har skrivit. I sitt original omfattar slutet exakt 1202 tecken inklusive blanksteg. Ni kommer då att ges några frågor i anslutning till övningen. Och få reda på vilken författare som har skrivit novellen.

3. Några av dessa frågor tar vi upp på vår workshop. Andra kommer ni att kortfattat få besvara skriftligt.

Efteråt fick studenterna veta att Cecilia Davidsson är författare till den berättelse som de själva hade skrivit alternativa slut på. De fick i samband med detta naturligtvis även se det slut som Cecilia själv hade skrivit.

Det visade sig att det bara på D-kursen fanns tid och möjlighet att ägna en workshop, omfattande fyra timmar, åt att diskutera hur de tio studenterna på avancerad nivå uppfattat övningen och om de blivit stimulerade av att utföra den. De tog tillfället i akt att även dryfta såväl nackdelar som förtjänster hos den. Utöver detta besvarade D-studenterna även skriftligen frågor i en enkät, som vi även riktade till studenterna på A- och B-nivå. Sammanlagt 60 studenter svarade på följande fem frågor: 
1. Hur styrda av den föregående texten upplevde ni att ni var då ni utarbetade ert eget slut? Och vad i denna text uppfattade ni som mest styrande, som mest avgörande och determinerande för det slut ni själva kom att utforma?

2. Hur förhåller sig ert eget slut till det som Cecilia Davidsson har skrivit? Är det någon inom er grupp som har råkat komma i närheten av originalnovellens slut? Hur ska man i så fall beskriva denna närhet?

3. Är det några av er som har skrivit slut som liknar varandra? Vad kan i så fall ligga bakom denna mer eller mindre gemensamma kreativa impuls? Och vari består likheterna?

4. Tycker ni att en skrivövning som denna är hämmande, tvångsmässig och klaustrofobisk, eller tycker ni att ni lyckas utvinna något frigörande ur den, exempelvis en aning om er högst personliga litterära egenart så som denna kanske manifesteras av det slut ni har valt att skriva?

5. Ställ en egen fråga med anledning av denna övning eller rörande de texter vi nu har samlat!

Det insamlade materialet är tämligen stort, i våra ögon ändå inte särskilt svårt att överblicka. Att det ter sig förhållandevis enkelt att överblicka kan bero på två saker, för det första att vi i själva skrivövningen inte gav studenterna mer utrymme än 1000-1800 tecken att åstadkomma något eget, för det andra att våra enkätfrågor visade sig fungera mer styrande än vi trodde att de skulle kunna göra - medan däremot seminariediskussionen på D-nivå blev överväldigande synpunktsrik och bitvis vildvuxen av allsköns hugskott och mer eller mindre relevanta infall.

Vi som initierade detta experiment i hopp om att det skulle visa sig vara både lärorikt och kreativitetsbefrämjande ska nu från olika utgångspunkter kommentera både övningen och resultatet. Vi har fördelat arbetsuppgifterna mellan oss.

Först skriver Tommy Olofsson om själva planen för övningen och sätter in experimentet i ett litteraturhistoriskt sammanhang, för att i sin artikel slutligen försöka kategorisera några frekventa typer av slut som förekommer i det insamlade materialet.

Därefter tar Cecilia Davidsson vid för att beskriva sin reaktion på att som författare få en av sina texter färdigskriven av andra människor och på så många olika sätt. Hon kommer att beröra några av de alternativa slut hennes novell har beståtts och beskriva hur läsningen av dessa kom att få en viss inverkan på hennes eget arbete med sin novell. Versionen som trycktes i bokform i Höga berg, djupa dalar skiljer sig nämligen i några avseenden från det manuskript vi gav studenterna att arbeta med.

Det är alltså i det följande fråga om två artiklar, tätt interrelaterade och kretsande kring samma litterära övning, men utgångspunkterna för dem är olika. Det är fråga om två varandra kompletterande perspektiv.

Vi har roat oss med att tilldela varandra varsin roll att leva upp till. Cecilia Davidsson ska spela rollen som Richard Furumo, författarens alter ego i Carl Jonas Love Almqvists bokserie Törnrosens bok, medan Tommy Olofsson får axla rollen som den styvnackat förståndige Herr Hugo, hovmarskalk och ägare av det fingerade jaktslott där den svärmiske Richard Furumos romantiska verk enligt Almqvists ramberättelse läses högt för 
en liten krets av mer eller mindre hängivna beundrare som andäktigt lyssnar och efteråt ibland diskuterar vad de har fått höra.

\section{Davidssonexperimentet (enligt Herr Hugo)}

”Dialog om sättet att sluta stycken” är ett verk av Carl Jonas Love Almqvist. Dialogen publicerades första gången 1835 i sjätte volymen av den så kallade duodesupplagan av Törnrosens bok. ${ }^{1}$

Dialogen utgörs av ett samtal mellan de två viktigaste karaktärerna i ramberättelsen till Törnrosens bok, Richard Furumo och Herr Hugo, som bland annat kommenterar och analyserar två av de andra verk som ingår i törnrosenserien, romanen Drottningens juvelsmycke och dramat Ramido Marinesco. Denna dialog har ofta uppfattats som en viktig källa för Almqvists litteratursyn. Forskare har framför allt framhållit den viktiga roll läsaren tillmäts som ett slags medskapare och subjektiv fullbordare av ett litterärt verk.

Almqvist framstår inte bara som en fullfjädrad romantiker utan även som en häpnadsväckande modern och framsynt litteraturteoretiker när han beskriver författaren och läsaren som "två samverkande faktorer till det arbete, som utföres” när ett litterärt verk förverkligas. Han drar sin tes mycket långt:

Och verket sjelf - som på papperet, der det ligger för ögonen, icke kan anses för färdigt mer än till det, i bokstäfverna befintliga, artistiska anslaget - blir oupphörligt mer och mer färdigt genom läsarne. Och emedan desse under tidernas lopp blifva fler och fler, så kan man säga, att författarens arbete sålunda ständigt allt vidare fortfar att förfärdigas, så länge verlden står. Innebär det ej en outtömlighet, en viss evighet, som icke saknar intresse? (Almqvist 1998: 178.)

Jo, det innebär en viss evighet som icke saknar intresse. Almqvist formulerar förbluffande tidigt tankegångar som enligt Bertil Romberg pekar ”fram mot våra dagars krav på en engagerad och medskapande läsare” (Romberg 1993: 109). Som konsekvens av sin övertygelse att författaren fullbordar sitt verk i samspel med sina läsare är Almqvist beredd att ta ytterligare ett steg, detta genom att som författare själv vinnlägga sig om att skapa texter som är öppna och därigenom tydligt bjuder in läsarna att vara medskapare.

Enligt Almqvist finns det i grund och botten bara två slags sätt att skriva. Det ena går ut på att författaren strävar efter att ge sina läsare "besked i allt” (Almqvist 1998: 177), så att verket framstår som avrundat och fullbordat, klappat och klart. Verket kan då framstå som fulländat och självtillräckligt samt tillmätas en existens oberoende av läsaren. ”Men man kan äfven skrifva på ett annat sätt”, hävdar Almqvist och beskriver sedan detta skrivsätt i följande ordalag:

\footnotetext{
1 Volymerna V-VII i duodesupplagan ingår numera alla tre i band 7 av den moderna textkritiska och kommenterade utgåva av C.J.L. Almqvist, Samlade Verk, som sedan 1993 är under utgivning i Svenska Vitterhetssamfundets regi. Bertil Romberg är den Almqvistforskare som har ombesörjt den textkritiska ederingen av hela band 7 och skrivit en vetenskaplig kommentar till utgåvan 1998. Det är i denna vetenskapliga utgåva vi har stiftat närmare bekantskap med Almqvists text, som har kommit att bli riktningsgivande för oss i vårt eget arbete.
} 


\begin{abstract}
Man kan låta bli att yttra allt; kanske ej en gång i orden lägga det hufvudsakligaste. Hvad man yttrar kan dock vara af sådan beskaffenhet, att det sätter läsaren i ett perspektiv, i en stämning, i en önskan och förmåga att gå fram $\mathrm{i}$ ämnets riktning - och han uppfinner på egen hand allt det öfriga osagda; ja kanske mycket mer, än som ens kunnat sägas af författaren.

Läsaren får då vara, ej blott läsare, utan äfven menniska: han får vara produktiv. Han bekommer tråden af författaren, men får gå med den på sitt sätt. Tråden måste likväl vara sådan. Att läsaren dermed ej löper annorstädes, än författaren ville, ehuru det kan ske i variationer efter olika läsares lynnen. (Almqvist 1998: 177.)
\end{abstract}

Almqvist låter Herr Hugo vara motsträvig när diktaren Richard Furumo lovsjunger det öppna konstverket och den medskapande läsaren. Han har allvarliga invändningar mot Furumos "sätt att sluta eller fullända stycken”, så att verk som romanen Drottningens juvelsmycke och teaterstycket Ramido Marinesco utmynnar i förbryllande slut och "att deröfver sväfvar en dimmighet af oupplösta motsägelser och en tvetydighet i utsägandet af det helas tanke”, varför Herr Hugo vänder sig till Richard Furumo och säger, ”att ditt sätt att sluta, liksom vore det icke slut, tycks vara genomgående hos dig” (Almqvist 1998: 169).

Herr Hugos invändning mot Richard Furumo påminner i hög grad om vad samtida litteraturkritiker skriver om Cecilia Davidssons sätt att avsluta sina noveller. Ända sedan debuten med En av dessa nätter (1994) har Cecilia Davidsson i sina hittills fem novellsamlingar med förkärlek odlat en sorts öppna eller gåtfullt undanglidande slut på sina berättelser. Hon är alltså alldeles uppenbart en författare i Richard Furumos anda, även om man kan gissa att hon för sitt arbetssätt har funnit inspirationskällor i sin egen samtid, i första hand amerikanska smutsrealister som Raymond Carver, sannolikt även författare som Marguerite Duras, Julio Cortázar, Alice Munro och, utan tvivel, Franz Kafka.

Carver betydde nog mer än någon annan för den våg av högt kvalificerad novellistik som kom att berika den svenska berättarkonsten under 1990-talet, den så kallade "novellboomens” decennium. Det var en våg som Cecilia Davidsson inlemmades i. Av alla dessa nya berättare i det mindre formatet kom hon att bli en av de mest framträdande och alldeles avgjort den som trognast hyllades av kritikerna. Hon har också visat sig vara novellen ganska trogen. Visserligen har hon på senare år även prövat sin vingbredd i större format och skrivit två romaner, men till skillnad från flera av sina generationskamrater har hon även fortsatt att skriva noveller och ytterligare förfinat sin redan från början ansenliga förmåga att förtäta en kort berättelse. Hon har skrivit tre nya novellsamlingar sedan millennieskiftet och 90-talets "novellboom".

Ett par recensenter karakteriserar novellerna i hennes senaste bok Höga berg, djupa dalar som "mästerliga”, medan andra besväras av det distanserande i hennes prosa och någon rentav karakteriserar den som "manierad”. Om man granskar recensionerna närmare, framgår att det är samma egenskaper i Cecilia Davidssons prosa som kan locka en kritiker att karakterisera den som mästerlig och en annan kritiker att benämna den manierad. Det är i båda fallen fråga om reaktioner på författarens sätt att låta mycket i berättelserna vara antytt mellan raderna, i ett slags undertext där det outsagda sväller och 
växer sig stort av möjliga betydelser och bibetydelser. ”Undertexten trycker på från alla håll”, klagar Marie Pettersson uppgivet i Sydsvenskan (2015-10-29), medan Bo Bjelvehammar i Tidningen Kulturen (2015-09-01) njuter av just detta fenomen och stimuleras av att författaren inte "visar facit i det som hon berättar” utan i stället bjuder in sina läsare: "då får du som läsare själv berätta vidare, inom dig, du får svara för efterbörden”. Man märker tydligt att något som starkt påminner om kontroversen mellan Herr Hugo och Richard Furumo ekar i mottagandet av Cecilia Davidssons senaste novellsamling.

Just Cecilia Davidssons berättartekniska skicklighet och förmåga att ladda sina noveller med ansatser till händelseförlopp i olika riktningar, så att de först verkar vara på väg att utvecklas åt ett håll men sedan plötsligt skruvas åt ett helt annat håll, är vad man kan beundra eller irriteras av i hennes prosa. Själv hör jag till beundrarna och tycker mig dessutom ha upptäckt hur sällsynt väl hennes noveller passar för en viss sorts övningar för studenter i kreativt skrivande. När jag nu denna gång lyckades övertala henne att släppa till en vid skrivövningstillfället ännu opublicerad novell för ett sådant experiment, var det inte första gången jag kom att använda någon av hennes berättelser i ett motsvarande pedagogiskt sammanhang. Redan för ett tiotal år sedan, långt innan vi blev kollegor vid Linnéuniversitetet, lät jag tre eller fyra årgångar av studenter arbeta med den första novellen i hennes första novellsamling En av dessa nätter. Det är en kort berättelse som heter "Min nye kille”. Jag lät studenterna få läsa halva novellen och uppmanade dem sedan att skriva den andra halvan på egen hand. Det var en övning som varje gång väckte stor förtjusning, inte minst i samband med att studenterna fick läsa Cecilia Davidssons eget mycket överraskande slut på historien. Det framstår nämligen som alldeles oväntat, även om man vid en omläsning märker att författaren har bäddat för det. En sådan övning kan man emellertid inte upprepa för många gånger. Efter andra eller tredje gången hade studenterna tydligen fått nys om att jag envisades med att ha den där övningen, så några av dem visste vem som hade skrivit novellen och hur originalet slutar.

Man kan ha olika skäl för att byta ut övningar. Före övningen på grundval av ”Min nye kille” hade jag under en följd av år låtit studenterna skriva ett nytt slut på en välkänd berättelse som de själva redan var bekanta med och hade läst i sin helhet, nämligen Hjalmar Söderbergs historiett "Pälsen”. Jag har i mina gömmor hundratals alternativa variationer av slutet på denna historiett, men även denna övning kom jag att skrinlägga. Det skedde när jag hade läst Christine Falkenlands roman Vinterträdgården (2008). Christine Falkenland skildrar en medelålders kvinna, Laura, som går på en skrivarkurs och med liv och lust börjar skriva poesi. Att formulera sig i skrift öppnar gamla igenslammade slussar i hennes inre. Hennes sensibilitet och livsnärvaro ökar. Hennes poesi är starkt känsloladdad. Några av hennes dikter återges i romanen, som annars domineras av hur Laura stegvis blir alltmer förälskad i en gift iransk kvinna och inleder ett innerligt erotiskt förhållande med henne.

Intressanta i vårt sammanhang är de inslag som rör Lauras medverkan i en distanskurs i kreativt skrivande. Lustigt nog får hon en gång en arbetsuppgift som är mycket lik en 
uppgift som jag själv under några år gav mina studenter vid Linnéuniversitet, någon gång även vid Författarskolan i Lund, en skrivövning som jag antagligen varken är den första eller sista att ge. Jag citerar ur romanen:

Hemläxan över jullovet är att skriva om Hjalmar Söderbergs "Pälsen”. Jag lämnar aldrig in uppgiften, utan skyller på att jag inte har haft tid. (Falkenland 2008: 94.)

Efter att ha läst dessa rader i Christine Falkenlands roman har jag känt ett oöverstigligt mentalt hinder mot att på nytt ge denna övningsuppgift. Laura struntar i att göra den. Då kommer nog alla att göra det.

Annars tror jag mycket på övningar av just det här slaget. De ligger i linje med något som Björn Larsson, den utmärkte romanförfattaren och professorn i franska, redan från början starkt betonade när han tog initiativ till Författarskolan i Lund, nämligen att det är nödvändigt att läsa mycket god litteratur för att själv kunna lära sig att skriva god litteratur. Då Författarskolan sjösattes 2002 som en tvåårig kurs på heltid, hade den ett kursmoment som sedan orubbat har funnits kvar genom alla år, "Läsa för att skriva”. Från starten 2002 och fram till 2010 undervisade jag på Författarskolan i Lund jämsides med min undervisning som lärare i kreativt skrivande i Växjö. En av de lärdomar jag tog med mig från kollegorna i Lund till kollegorna i Växjö hade att göra med hur man kunde experimentera med praktiska skrivövningar i anslutning till skönlitterära verk som studenterna hade fått läsa på kursen. Det är i det sammanhanget man ska se mina övningar med "Pälsen” och "Min nye kille".

Övningarna med "Pälsen” och ”Min nye kille” skiljer sig från varandra såtillvida att studenterna i det förra fallet hade kännedom om Söderbergs avslutning av sin historiett, medan de inte kände till hur Cecilia Davidsson hade utformat slutet i "Min nye kille" eller ens att det var hon som hade skrivit den text de fick att arbeta med. Det nya Davidssonexperimentet, alltså att låta studenterna arbeta med en i bokform ännu opublicerad novell, "Vad är det som säger att du inte redan älskar mig”, skiljer sig i sina förutsättningar radikalt från de båda tidigare övningarna, allra mest tack vare författarens egen aktiva medverkan i projektet. Det är just denna författarens medverkan som gör experimentet extra intressant, föreställer jag mig, men även studenternas insatser är naturligtvis som alltid av stort intresse. Hur artade sig dessa?

För det första ska sägas att vi fick anledning att glädja oss mycket över den starkt positiva respons som övningen gavs i vår enkät om den och i de diskussioner som fördes i samband med seminariet för D-studenterna. En del av denna bejakelse måste naturligtvis tillskrivas studenternas hygglighet och beredskap att bidra till trivseln inom ämnet. De ville väl helt enkelt inte ifrågasätta en övning som två av deras lärare hade hittat på för deras räkning. Ändå tyckte vi oss ha lyckats manövrera frågorna i enkäten på ett sådant sätt, att det skulle kunna bereda väg för problematiserande synpunkter. Första frågan var hur styrda studenterna tyckte sig ha blivit av uppgiften och av den berättelse som förelagts dem att fullborda samt vad i denna berättelse som varit mest determinerande för deras egen utformning av slutet. Att de flesta uppfattat sig som styrda av 
den förelagda novellen kom förstås inte som någon överraskning, och det var långtifrån alla som i detta upplevde något hämmande, men intressant var att upptäcka att det från student till student kunde skilja sig enormt mycket rörande vilka element i texten de hade känt sig styrda av och tyckt sig vara tvungna att foga sig efter i utformningen av ett slut på historien.

”Jag tycker att övningen är aningen hämmande, men samtidigt intressant och ganska rolig", skriver en student och sätter sedan fingret på en punkt som även flera andra berör, nämligen det i hennes tycke alltför begränsade utrymme som erbjöds dem för att själva göra ett slut, alltså 1000-1800 tecken:

Det som hade lyft övningen för min egen del hade dels varit att ges utrymme att skriva längre, dels att slippa vara bunden till att försöka efterlikna stilen i originalet. Jag tror att var och ens särpräglade stil hade synts mer i texterna då och också att variationerna mellan sluten hade blivit ännu större. Det var dock intressant att se hur olika sluten blev nu - trots att övningen var så pass styrd.

Detta enkätsvar är intressant på minst två sätt. Det första är att vi i instruktionen aldrig begärde att studenterna skulle "försöka efterlikna stilen i originalet” utan bara "följa den dialogteknik som redan är knäsatt i berättelsen”. Ändå visar det sig att många har eftersträvat en mer långtgående trohet mot förlagan, i varje fall att döma av enkätsvaren. De har uppfattat själva texten som starkt styrande och som om de har tyckt sig vara tvungna att följa något i den, omväxlande kallat exempelvis "stil” eller "ton”, men det paradoxala är att sluten ändå visade sig bli så olikartade, alltså som om texten i själva verket inte alls kom att vara så styrande som flera studenter ändå upplevde att den var. I denna paradox ligger den andra poäng som är av intresse i studentens svar ovan, nämligen hur en text som var så styrande kunde dra iväg med studenternas fantasier åt så många olika och ofta alldeles oförenliga håll.

En student på A-nivå skriver: ”Mitt eget slut liknar inte alls Cecilias. Mitt är mer konkret och har ett tydligare avslut. Jag tycker inte heller att någon kommit i närheten av originalet. De flesta av oss har försökt att knyta ihop säcken, medan Cecilias novell har ett öppnare slut som väcker fler frågor.” Och så här snarlikt formulerar sig en annan i A-gruppen: ”Ingen i vår grupp har skrivit exakt som Cecilias slut. Cecilias slut är väldigt öppet, man vet inte vad som egentligen händer i slutet.” Att jag här väljer att plocka svar från studenter i A-gruppen beror på att det var hela 43 studenter i den gruppen som skrev ett eget slut på historien. Ändå kan man, precis som dessa studenter, helt riktigt konstatera att ingen av dessa drygt fyrtio skribenter åstadkom en avslutning som ens påminner om Cecilia Davidssons, detta trots att flera av dem känt sig styrda av hennes berättelse. Studenternas slut uppvisar betydligt större likheter inbördes, med varandra, än vad de alltså har med Davidssons. I någon mening måste detta utgöra ett visst mått på Cecilia Davidssons originalitet som berättare, därmed inte sagt att originalitet i sig måste vara ett kännetecken på litterär förmåga eller kvalitet, men saken är likväl värd att notera. 
Värt att notera är även att bland studenterna på D-nivå, inalles tio, kände bara en av att förlagan styrt skrivakten på ett sätt som blev besvärande. Man ska naturligtvis akta sig för att dra några stora växlar på en sådan iakttagelse, men man kan heller inte bortse från möjligheten att merparten av D-studenterna i sitt arbete verkligen kände sig friare än Astudenterna och att detta i så fall kan ha berott på att de var mer vana vid att ställas inför skrivövningar av liknande karaktär eller - ännu viktigare att framkasta som en möjlig förklaring till denna skillnad - genom kursernas gång tillskansat sig ett stegvis allt större självförtroende som skribenter och därför fann det mindre problematiskt att utforma sina slut. Att D-studenterna kände sig mindre snärjda av förlagan än A-studenterna tycktes vara kan alltså ha berott på deras större självförtroende inför arbetsuppgiften. Hur som helst verkar det sannolikt att deras grad av påverkansångest har varit mindre, för att i detta kanske överraskande sammanhang låna ett välkänt och slitet men i denna konkreta pedagogiska situation mycket talande försvenskning av ett begrepp myntat av Harold Bloom i hans bok The Anxiety of Influence (1973).

På vilket sätt kan då studenternas slut sägas vara inbördes besläktade och möjliga att indela i olika typer? Utan att göra våld på det insamlade materialet i form av sextio slutversioner av den förelagda novellen kan man urskilja fyra typer av slut, typer som tycks kunna fånga upp praktiskt taget alla de slut som har skrivits. Det är fråga om typer som i vissa fall har kombinerats med varandra inom ramen för ett och samma slut, men oftast förekommer de i mer eller mindre renodlad form. Man kan tveka inför uppgiften att ge sammanfattande karakteristiker av slut som kan te sig ganska olikartade. Inte desto mindre förekommer dessa typer av slut och bör ges åtminstone provisoriska benämningar.

En ganska vag men inte desto mindre urskiljbar typ kännetecknas primärt av psykologisk realism. I denna typ av slut sker inte nödvändigtvis något spektakulärt eller omedelbart iögonenfallande. I flera fall lämnar kvinnan helt enkelt lägenheten och den märklige mannen, markerar ett avstånd till honom, ofta ett både fysiskt och mentalt avståndstagande. Mannen framstår som äcklig och motbjudande, kanske avskyvärd, men kvinnan gör inte så mycket annat än att hon just avlägsnar sig, varvid hon i något fall svär till och i ett annat tänker att män i allmänhet är för djävliga. Inom ramen för denna psykologiska realism kan en hel del överraskningar förvisso förekomma - till exempel att ytterligare en kvinna plötsligt kommer ut ur ett rum i lägenheten och visar sig vara mannens älskarinna, sambo eller kanske hustru, som säger: ”Jag går och lägger mig nu, älskling” - men det är hela tiden fråga om händelseförlopp och reaktioner som är förenliga med en ganska handfast realism, både i sak och i psykologiskt hänseende, i sättet att beskriva fiktionens primära aktörer, mannen och kvinnan.

Övergången från psykologisk realism till ganska utpräglad sexskildring sker längs en glidande skala, men påfallande många studenter har tydligen känt ett behov av att snabbt vidareutveckla det erotiska motivet i berättelsen. Antingen kastar sig mannen och kvinnan kärlekshungrande i varandras armar eller kommer det sexuella samkvämet att ta sig mer extraordinära former. En identifierbar subkategori i de slut som utmyn- 
nar i sexskildringar är den där SM-inslag spelar en helt avgörande roll. Häri avspeglas en populär trend inom samtidens triviallitteratur, kan man gissa, men avvikelserna från triviallitteraturens mönster är påfallande. Oftast är det nämligen kvinnan i berättelsen som är den dominanta och som bryskt ger sig i kast med mannen för att tukta honom till sexuell underkastelse. Ibland röjer dessa övergrepp fantasier om ett slags ohämmad kvinnlig driftbejakelse på mannens bekostnad. Andra gånger utgör de huvudsakligen snabbt iscensatta seanser vars primära syfte tycks vara att visa hur en kvinna kan läxa upp en sluskaktig karl.

En annan urskiljbar typ av slut låter berättelsen utmynna i ett brott, något som gör att novellen i sin helhet, alltså med retroaktiv verkan, kommer att framstå som en ganska konsekvent genomförd kriminalberättelse. Om det blir mannen eller kvinnan som blir tagen av daga växlar mellan versionerna, men oftast är det mannen som stryker med, antingen genom att han dräps till följd av kvinnans uppblossande vrede eller genom ett överlagt mord vars skäl blir klargjorda först i slutet av historien. Även denna typ avslut har förstås triviallitterära drag, men de behöver ändå inte nödvändigtvis anknyta till kriminallitteraturens vanliga förlopp eller ordinarie rekvisita. I ett par fall blir de kriminallitterära inslagen parodiskt uppförstorade och humoristiskt turnerade, på ett sätt som gör att man kan börja misstänka att de två odygdiga studenterna har roat sig med att under humoristiska former ta livet av en eller annan fiktiv person som deras lärare har prackat på dem. Det ligger nära till hands att uppfatta deras versioner som metakommentarer till skrivövningen som sådan. En av studenterna lyckas till och med konststycket att ha ihjäl både kvinnan och mannen. De parodiska kriminalberättelserna utgör emellertid undantag. De flesta är ganska konventionellt utformade.

En fjärde kategori av slut kan identifieras i de fall studenterna laborerar med övernaturliga inslag som ger skildringen karaktär av mer eller mindre spöklik fantasy. Det är en förvånansvärt stor och enkelt urskiljbar kategori. Och uppfinningsrikedomen är stor! Hos en student visar det sig att kvinnan i själva verket är Döden, som har kommit för att hämta mannen. Mannen sätter sig på tvären - "Bara så du vet. Jag följer fan inte med frivilligt." - men ger genast efter då hon tar honom i handen och sakta leder honom ut genom den trånga hallen till trapphuset, för när han till sist förstår vem hon verkligen är, det vill säga Döden, erinrar han sig han ju faktiskt redan älskar henne: ’Det finns de som älskar när döden kommer och tar dem.” Ett besläktat slut möter oss hos en student som avslutningsvis förenar Eros och Thanatos, sexualitet och död, då hon låter kvinnan börja förföra mannen och drar in honom i en dans för att genom en kyss, av allt att döma en dödskyss. När hon kysser honom, sticker hon in handen under hans skjorta för att på så vis komma åt hans hjärta, och han "protesterade inte när hon lät händerna glida in under hans skjorta och greppa det pulserande hjärtat". Det finns fler varianter, med mer eller mindre övernaturliga inslag och mer eller mindre märkbara mytologiska anspelningar.

Flera av de studenter som har skrivit övernaturliga slut tycker sig ha funnit visst fog för dem i sekvenser de har funderat på i Cecilia Davidssons novell, exempelvis i kvinnans övertygelse om att hon ska kunna få mannen att le och kanske rentav påverka honom i 
kraft av sina egna tankar. I mina ögon har de inte haft särskilt mycket att gå på, men det de har funnit visar sig alltså ha varit tillräckligt för att driva deras fantasier åt fantasyhållet. Och har de därmed inte kommit i närheten av det slut som Cecilia själv har skrivit? Vad är det för besynnerligheter kvinnan ägnar sig åt i slutet av originalnovellen, när hon borrar in sitt finger i ett hål i en tavla och då på något underligt sätt tycks kunna manipulera mannen. Är det trolldom hon utövar? Eller vad händer? Vi får se vad Cecilia själv, alias Richard Furumo, har att säga om denna gåta.

En gåta vi gav studenterna att fundera på var om de trodde att det var en kvinna eller en man som hade skrivit den berättelse de fick att arbeta med. Bakgrunden till att vi ställde denna fråga, märk väl vid sidan av själva enkäten, var att Cecilia själv var nyfiken på vad studenterna skulle svara, detta helt enkelt därför att hon av läsare och i recensioner av sina böcker ganska ofta fått påtalat att hennes stil är "manlig”. De svar som våra studenter gav på denna fråga gladde oss mycket. Å ena sidan gladde de oss genom att gissningarna inte visar någon signifikans åt vare sig ena eller andra hållet, att utfallet av gissningarna praktiskt taget blev 50/50, alltså lika många gissningar på att en man skrivit novellen som på att en kvinna hade gjort det. $\AA$ andra sidan blev vi, efter den första förvåningen, ännu gladare över att så många protesterade mot vår fråga och ytterst motvilligt eller inte alls besvarade den, detta med hänvisning till att frågan kunde misstänkas vara ett knep att locka studenterna att avslöja sina egna fördomar om vad som är kvinnligt och vad som är manligt.

Författaren är en man, den slutsatsen kommer en av studenterna fram till efter en ingående textgranskning som utmynnar i konstaterandet: ”Jag inser att denna min analys speglar mina egna, och förmodligen en stor del av samhällets, fördomar om män och kvinnor.”

Och så här låter det hos en student som vägrar att ens befatta sig med frågan: ”Jag avhåller mig ifrån att gissa huruvida författaren av texten identifierar sig som kvinna eller man. /.../ Möjligen hade det varit intressant om det hade varit en kurs i språksociologi där deltagarna haft lite mer på fötterna och inte bara gissade vilt medan de fällde mer eller mindre sexistiska kommentarer.”

Med svar som dessa blev vi lärare särskilt nöjda, eftersom ingen av oss anser att det finns något specifikt kvinnligt eller manligt sätt att skriva eller, närmare bestämt, något specifikt skrivsätt som är bundet till författarens biologiska kön.

Eller?

\section{Det öppna slutet (enligt Richard Furumo)}

En kväll i augusti 1996 på Prinsens uteservering: Några väninnor är där, jag minns inte exakt vilka. Minns inte om hon är en av dem, hon som långt senare blev ”Anna” i ”Vad är det som säger att du inte redan älskar mig”, eller om jag pratar med henne i en telefonkiosk. Det viktiga är detta: av "Anna” får jag veta att det pågår en fest på Lundagatan på Södermalm och att det är OK att bara gå dit. Lite motvilligt bestämmer jag mig för att göra detta. Jag är inte särskilt festsugen, trots att jag den här kvällen är barnfri för 
första gången på mycket länge. Kanske är detta den allra första helgen sonen bor hos sin pappa.

Det är någonting med stämningen den här kvällen, och med kvinnan, hon som är jag, som stannar kvar. Hon som tycker att hon borde ta chansen och gå på fest, ha lite roligt. Hon är ju fri nu. Det finns ingen i hennes närhet som kan komma med synpunkter på vad hon ska göra och vem hon ska vara. Hon kan välja att vara vem som helst.

Festen, då?

Jag har ett minne av att stå på trottoaren på Lundagatan och titta upp mot ett öppet fönster.

Jag har ett minne av att befinna mig inne i en lägenhet på Lundagatan på en fest som håller på att ta slut.

Jag har ett minne av en fest i en liten lägenhet där folk dansar, ”Anna” är en av dem. Jag har ett minne av att gå hem i den tidiga morgonen, över Medborgarplatsen, ensam.

En pjäsidé: Pernilla August kommer in i ett kök där en ensam man sitter och äter. Det är mitt i natten, de känner inte varandra. Mannen säger att hon är lik skådespelerskan Pernilla August. Antingen låtsas hon nu inte om att hon är den "riktiga” Pernilla August, eller så spelar hon sig själv, det vill säga skådespelerskan Pernilla August, eller så är hon en skådespelerska, som råkar vara Pernilla August, som spelar en kvinna som mannen i köket tar för Pernilla August.

En dagboksanteckning i juli 2006:

En idé: kvinnan som alltid/ofta blir tagen för en viss skådis, Pernilla August (?), och är på väg att ge upp och gå med på att hon och skådisen är samma person. Går till en fest, som tagit slut när hon kommer in. Hamnar i köket där en kille frågar om hon är den där skådisen.

- Vet du att du liknar hon den där ...

- Pernilla August?

- Ja, just det. Jäkligt likt faktiskt. Trots att du är blond. Hon är mörk, va?

Sedan följer en ostrukturerad skiss på ett par sidor, skriven i jagform, som börjar med att kvinnan går in genom den öppna dörren till lägenheten: "Det var bara att kliva på, mitt i staden, mitt i natten”. I vardagsrummet får hon syn på ett ihopslingrat par, förenat i en kyss. ”Jag hade sett det förut”, konstaterar hon. Hon söker vidare, och i köket hittar hon en man som sitter hukad över en tallrik med överbliven plockmat.

Det var alltför sent på natten för att han skulle be om ursäkt. Han var fyllehungrig, och det var jag också. Den nätta lilla middagen på stan hade för länge sedan sjunkit undan. Han tittade upp, och så fick han den där undrande glimten $\mathrm{i}$ ögat.

- Sätt dig, sa han. Jag tror inte att jag orkar äta upp allt själv.

Jag hade gjort slingor i håret och färgat ögonbrynen och börjat klä mig i kläder som bröt mot allt vad jag ansåg vara smakfullt, men det hjälpte inte. Den där Pernilla August hade tagit mig i besittning.

Skissen materialiserade sig i två utkast som jag stoppade in i en pärm och glömde bort. Två år senare hittade jag dem i samband med att redaktören på tidskriften Ordkonst 
hörde av sig och frågade om jag ville skriva en novell på temat "kulinariska äventyr". Jag hade varken tid eller lust att skriva något helt nytt, och i utkasten fanns ju redan det "kulinariska”, i form av fyllehunger och italiensk plockmat. Perfekt. Det var med andra ord en beställning som fick mig att färdigställa novellen, som kom att publiceras i Ordkonst (2008:4) under temarubriken "Författare skriver om mat”. Fast novellen var ju inte riktigt färdig. När jag några år senare började sammanställa en ny novellsamling fick den hoppa tillbaka i manusform. En sista finslipning återstod. Och det var i det skicket den presenterades som övningsobjekt för våra studenter i kreativt skrivande.

Jag återvänder till utkasten, som jag läste om alldeles nyligen. Det första jag slås av hur usla de är, och hur bra slutresultatet är i en jämförelse. Det är så tydligt att omskrivningar är min arbetsmetod.

I en av versionerna kommer novellen till min stora förvåning till ett läge då både protagonist och antagonist sitter och gapskrattar, kvinnan så att hon håller på att krevera. Mannen har gett henne rådet att le; hon presterar ett "millimeterleende”, mannens mungipor går i taket, och då måste hon skratta åt honom. Glädjen stegras och blir närmast hysterisk när två yrvakna personer dyker upp i dörröppningen och är "törstiga på vatten”. Skrattet börjar göra riktigt ont i kvinnan, det är inte längre roligt, hon försöker stoppa sig själv, ”men blev själv stoppad, av den där obehärskade arkitekten, och mellan snyftningarna försökte jag förgäves förklara för honom att han höll på att ta livet av mig”. Arkitekten?

En notering i blyerts: ”Jag vaknade nästa morgon av att jag blev slickad i ansiktet av en vit pudel."

Det andra utkastet förstår jag mig uppriktigt sagt inte alls på. I det slutet är mannen på toaletten. Då passar kvinnan på att snappa åt sig mannens plånbok som hela tiden legat på köksbordet. Hon öppnar den och kollar snabbt på körkortet.

När han kom tillbaka satt hon där och log.

- Vad är det, har det hänt nåt? Du ser ut som om du vunnit högsta vinsten.

Jag ryckte på axlarna.

- Det bara kom. Inifrån.

- När du ler ... Du ser ut som ... Vendela?

Han skakade på huvudet åt det han just sagt: Vendela. Jag kunde inte hjälpa honom. Jag hade ingen aning om vem Vendela var. Han sjönk ihop på stolen. Jag förstod att han inte tänkte följa mig till dörren.

Varför nämna allt detta? Förtjänar den aktuella novellen sådan uppmärksamhet? Nja, kanske inte så mycket för sina eventuella litterära kvaliteter som för att belysa den krumbuktande tillblivelsen av en novell - och ett slut.

Skrivövningen ledde in mig på denna väg, och den har varit mycket lärorik. Jag fick anledning att rekonstruera en arbetsprocess och skärskåda mina beslut och brist på beslut i densamma. Jag konstaterar att novellen växte fram stegvis, att jag testade och ratade ett flertal olika slut innan jag kom fram till det "rätta". 
Jag konstaterar att det kan ta tio år att skriva en novell.

Jag konstaterar också betydelsen av att en redaktör hör av sig.

Till detta ska läggas själva experimentet, som kom att bli en del av arbetsprocessen. Mer än jag hade räknat med. Övningen slutfördes under vårvintern 2015. Vi hade ett resultat - som jag inte direkt kastade mig över. Jag behövde ta det i omgångar. Novellsluten var jag inte ens säker på att jag skulle läsa innan min egen version var inom tryggt förvar mellan hårda pärmar. Fast överdriver jag inte nu? Novellslutet var vid den här tidpunkten redan i hamn. Det var så genomtröskat att jag upplevde det som omöjligt att rubba. Övriga delar i novellen satt inte lika säkert. Jag var inte helt nöjd, därför också mottaglig för andras synpunkter.

Det ingick inte i övningen att för studenterna kommentera ursprungsnovellen, men synpunkter och kritik smög sig ändå in via deras svar på frågorna. Inte minst frågan om könstillhörigheten på författaren öppnade upp för kritiska synpunkter, ja den tiggde om det.

Föga förvånande pekade studenterna ut sådant som jag är hyfsat säker på att jag hade plockat bort eller modifierat ändå, innan novellen gick i tryck. Det kan förstås även vara en efterkonstruktion. Det jag med absolut säkerhet vet är att studenternas kommentarer fick mig att skärpa blicken på ett sätt som annars sällan sker. Det blev i slutändan en bättre novell; aningen tydligare, aningen mer sammanhållen. Totalt gjorde jag ett tjugotal ändringar i den version som studenterna fick läsa.

Språket i novellen är rakt och enkelt, men det hade också på några ställen smugit sig in en smula mer formell eller "stolpig” ton. Denna karakteriserades som antingen "manlig” eller "kvinnlig”, lite beroende på vilka ord det gällde. Några exempel på ändringar jag gjorde i slutversionen: "Han iddes inte svara” blev "Han brydde sig inte om att svara”. "Bjärt” ändrades till "gräll”. ”I den påföljande tystnaden” blev till ”I tystnaden som följde”.

Jag vill också nämna följande parti:

Han reste sig upp och han var verkligen så lång som hon hade föreställt sig, säkert över en och nittio. Skulle han dra ner gylfen nu och dra fram något i hästväg så att hon skulle börja skratta av lycka?

Den andra meningen i citatet hamnade i papperskorgen. Redan när jag skrev den anade jag att den skulle gå den vägen, och resultatet från skrivövningen skyndade på processen. Jag skrev den för att jag tyckte den var rolig att skriva, och det är ett problem med den: den är för vitsig. Den sticker ut, tar för mycket fokus, associerar onödigt mycket till pornografins föreställningsvärld. Jag tror att jag tänkte så här: kvinnan i novellen har föreställningar om den långa mannen: han är "en sådan” som skulle kunna dra ner gylfen och visa upp ”något i hästväg” för att göra kvinnor på gott humör. Det vill säga: hon tror att han tror att det skulle fungera. Hon kliver in i en fördom (om vad män tror att "kvinnor vill ha”) och anammar samtidigt en viss jargong.

Jag tror att ingenting av det jag har försökt säga här kommer fram i själva texten. 
Alla val jag gör när jag skriver signalerar något. Självklart förstås, men det skadar inte att bli påmind om detta. Det där slumpmässiga, det där inte helt genomtänkta, den där snitsiga formuleringen, det där man kan gilla för att det "ser bra ut" - allt detta tillskrivs ett värde eftersom det de facto har hamnat på boksidan.

Signaler, ja. Men receptionen är självklart inte entydig. Det har också varit en underbar lärdom. Den stackars Tomas Ledin, vars vemodiga låt "Blå blå vindar och vatten” ljuder i novellens inledning, kom att hamna mitt i skottlinjen. Inte låten alltså, utan artisten. Låtvalet är helt medvetet från min sida. För mig är Tomas Ledin de snälla grabbarnas Ulf Lundell: enkel, välstädad, trallvänlig. Han signalerar yta, normativitet, svenskhet. En student (kvinna) som gissar att författaren är en man motiverar detta bland annat med att "det i bakgrunden spelas en Tomas Ledin-skiva. Min tolkning är att en kvinna i stället hade belyst lukter, känslor och lägenheten i helhet.” En annan student, också kvinna, tar Ledin som en indikation på att novellen är skriven av en man "50 plus”. En tredje student fick anledning att undersöka sina förutfattade meningar angående Ledin, som hon inledningsvis skrev gillades av män i hennes egen ålder (sen medelålder). Men efter research bland män i olika åldrar kom hon fram till följande: "ingen tycker om honom eller hans musik. Han är visst en fjant iaf. Så jag får släppa min förutfattade mening om Tomas Ledin och manligt.” Ytterligare två kvinnor nämner Ledin som könsmarkör, dock inte för samma kön. Valet av en låt av Tomas Ledin övertygar en manlig student om att författaren till novellen måste vara kvinna: "Min kvalificerade gissning är att en man skulle valt sin låt med betydligt större omsorg, och därmed lagt vinn om att inte i efterhand kunna beskyllas för att ha musikaliska preferenser som är så outgrundligt patetiska, fjolliga och helt enkelt simpla."

Enligt den här studenten tar författaren (undertecknad) en stor risk genom att överhuvudtaget nämna Tomas Ledin i en text. En man skulle inte ta en sådan risk, även om en låt av Ledin skulle göra sig utmärkt i textens sammanhang. Endast en kvinna skulle göra det. Det är inte ens ett risktagande. Hon kan låta sina gestalter lyssna på "töntig” musik utan att själv bli anklagad för att ha medioker musiksmak. Och om hon ändå skulle bli anklagad för det: who cares? Så här långt har jag aldrig reflekterat, trots att jag vet att musik är ett allvarligt ting, särskilt då för män.

Ett tillägg: studenten som citeras ovan har själv ingenting emot Tomas Ledin, men han är väl medveten om att andra har det.

På sätt och vis har det som framkom genom den här klumpiga frågeställningen varit det enskilt mest lärorika med uppgiften för mig personligen. Lärorikt på vilket sätt har jag inte funderat färdigt kring, men jag har fått nyväckta tankar kring mitt eget uttryck. Rent allmänt tycker jag att det är nödvändigt att blotta föreställningar och fördomar, inte minst för att kunna utmana dem, men också för att det säger något om människan och det samhälle vi lever i. 
Sluten, till slut

I slutet av maj 2015, bara några dagar innan jag skulle lämna novellmanuset med de absolut sista ändringarna till redaktören, bestämde jag mig för att ta tag i sluten. Tio skulle jag läsa, för att inte bli överväldigad. Jag sammanfattade varje slut mycket kort för mig själv:

1. Rollspel, lek med sex.

2. Mannen följer henne ut i hallen. Kräks upp maten. Sex.

3. Kvinnan hemlös? Han vill bjuda henne på oöppnat vin innan hon går.

4. Kvinnan kommit dit efter tips från Anna, men mannen är inte den hon trodde han skulle vara.

5. Kvinnan får honom dit hon vill (förmodas vilja): i säng. Han tar fram en flaska whiskey.

6. Hon skadar sig, han slickar blodet från foten. Hon planerar att döda honom.

7. Hon tar makten över situationen, genom tankekraft. Stannar över natten.

8. Perspektivet övergår till mannens. Hon vill leka något slags rollspel. Mannen hennes pappa?

9. Hon går därifrån, blir antastad. Ringer till Anna och klagar på att hon tipsade om ett sånt svin.

10. Han går och lägger sig när hon inte vill gå hem. Säger något om att han inte ska lyssna på vad Anna säger. Hamnar i hans säng. ”Äntligen”.

Jag märkte att jag tyckte sämre och sämre om novellen ju fler slut jag läste. Den framstod enbart som plump och könsstereotyp. Min läsning påverkades också av att jag hade studenternas indirekta kritik molande i bakhuvudet.

Först ett halvår senare läste jag samtliga slut. Novellen var klar, jag var nöjd med den. Därmed var också "faran” över. Nu läste jag med helt andra ögon, utan motstånd och rädsla, och då kunde jag plötsligt se den kreativitet, och ibland frenesi, med vilken studenterna gett sig i kast med uppgiften. Jag tror att några haft riktigt roligt medan de skrev. Sluten är inte dåliga, de är möjligen inte helt färdiga. Jag kan inte låta bli att ställa mig frågan hur resultatet hade blivit om studenterna hade lagt ner ens en bråkdel av den tid jag själv ägnade åt mitt eget slut.

Inget av studenternas slut är naturligtvis mer "rätt” än något annat. Skrivövningen gick inte ut på att lösa en gåta utan på att utmana sig själv genom att kliva in i en annan författares textvärld. Det jag har letat efter när jag har läst texterna är något som jag känner släktskap med. Jag hittar tre eller fyra slut som jag upplever hamnar på ungefär samma frekvens som mitt eget, i tonläge, språk eller ansats. Av dessa skulle jag vilja lyfta fram detta:

Han svepte med handen över resterna på bordet som för att visa vad han menade. Hon lät blicken glida över hans långa smala fingrar och kände i fingertopparna hur det skulle vara att smeka dem. Följa handryggen och fortsätta upp över hans arm. 
"Anna sa att det skulle vara party hela natten. Och jag har gått långt”. De gulgröna ögonen reflekterade lampan vid spisfläkten. Såg de där örsnibbarna och kände att det bakom den mjuka huden pulserade något varm och mjukt.

”Jag tänkte nog gå och lägga mig. Är faktiskt skittrött.”

En inbjudan, tänkte hon.

"Jag mår illa och det finns inget kvar här att göra", sa han plötsligt och reste sig.

"Du skulle nog inte ha slabbat i dig det där feta, sa hon och nickade mot resterna. "Njurarna du vet”. Nu såg hon svett tränga fram på hans panna. Blanka, svällande droppar trängde ur porerna och banade sig väg nerför hans tinningar och kinder.

”Jag tror det är bäst att jag hjälper dig i säng”. Hon ställde sig upp och sträckte fram handen mot honom. Hans hjärta pumpade nu i full kraft under den blå skjortan. Hon hörde dånet och såg bröstkorgen häva sig. Ögonen smalnade till tunna springor när han försökte böja sig framåt, och smärtan tog i.

"Det är du, va?” viskade han och stapplade ut mot vardagsrummet där musiken börjat om igen. Blev stående i dörrhålet, med handen i ett grepp om karmen.

"Kom", sa hon, "vi dansar". Hon la armarna runt hans hals och drog in lukten av svett och salami. Kände honom andas med korta ytliga andetag.

"Såja, mumlade hon, "såja”. Han snyftade stilla när hon la handen bakom hans nacke, drog ner hans huvud och kysste honom. ”Det är så här vi vill ha det, eller hur?” Han nickade knappt märkbart, och protesterade inte när hon lät händerna glida in under hans skjorta och greppa det pulserande hjärtat.

Jag tar mig friheten att bortse från vampyrtemat, som lägger sig som ett förklarande raster över hela novellen. När detta är gjort får vi i bägge versionerna en kvinna som utövar någon form av makt över mannen, utan att ens behöva peta på honom. Han drabbas av fysiska besvär, det går åt hjärtat till. Men det är ju inte heller omöjligt att han de facto blir sjuk, mer i studentens novell, mindre i min egen, på grund av de flottiga excesserna $\mathrm{i}$ köket. Trolldom eller inte: det är bara att välja. Att kvinnan i studentens version greppar mannens hjärta kan uppfattas både som en våldsam hämnd (hon kramar sönder hjärtat eller står i begrepp att slita ut det och kasta det på sophögen) eller som en kärleksgest, om än en påflugen sådan.

Sammanfattningsvis: maktförskjutningen, osäkerheten om vad som faktiskt händer i köket och öppenheten i slutet, som ändå inte tillåts rinna i väg hur som helst, gör att jag tycker att det här slutet går originalnovellens ärende.

Åtskilliga av sluten är ganska bombastiska. Det är inte förvånande. Övningens art, med starkt fokus på just slutet och med ett begränsat manöverutrymme, inbjuder till denna impuls. Sex- och våldimpulsen, skulle man kunna tillägga. I novellen kliver en kvinna in hos en främmande man mitt i natten. Varför? Ja, ytterst handlar det kanske om sex. Men sex handlar sällan om dess rena praktik. Jag kan inte påstå att jag är helt på det klara med vem den där kvinnan i novellen är, men hon är i alla fall inte sugen på att ligga med den där kronärtskocksätande mannen. Vad vill hon då? I något av de tidiga utkasten ville hon mest vila benen. Hon hade gått mycket långt. Jag återkommer till henne. 


\section{Slut eller avslut}

Slutet på "Vad är det som säger att du inte redan älskar mig" har väckt herr Hugos nyfikenhet. Han är inte direkt missnöjd, men tycks ha svårt att komma till ro med att kvinnan utan närmare förklaring står i hallen och borrar in ett finger i en tavla. Är det trolldom hon utövar? frågar han sig.

I det här läget är det dags att ta på sig Richard Furumos mantel och gå till försvar för det "dimblåa" i tillvaron.

Det är icke af begär att vara underlig eller med flit mörk, utan emedan tingen äro så: barret, som myran drar, ej mindre än stjernan, som fästet bär. Sådan är ock hvarje sann och verklig händelse i menskliga lifvet. Att den målas af konsten sådan den är, kan det vara ett misstag? Nej. Det är derföre ej genom ett konstmakeri jag sökt slingra mig undan det dimmiga i don Juans slut, utan äro dylika dimmar (omgifvande det klara med en krans af blånad) naturens och den sanna tillvarelsens tafla. (Almqvist 1998: 170.)

Rader som dessa får mig att beklaga att jag inte hittade fram till Almqvist när jag tog mina första stapplande steg som författare. Han kunde ha blivit en inspirerande följeslagare, någon att luta sig emot. Mycket av det jag själv haft svårt att sätta ord på formulerade han så exakt och vackert redan för hundraåttio år sedan.

Dimmighet, motsägelser och tvetydighet var de ord Per Daniel Amadeus Atterbom använde när han kritiserade slutet i dramat Ramido Marinesco, som han "i ästhetisk hänsigt" annars bedömde som "det bästa af allt, hwad Törnrosens Bok hittills innehåller", som han formulerar saken i sin recension i Svenska Litteratur-Föreningens Tidning den 18/2 1835 (Almqvist, 1998: XVIII). För undertecknad klingar sådana ord vackert. Jag lägger gärna till ordet "besynnerlig”, som en kritiker använde i en recension av min allra första roman Sjunken hjärna (2005).

Men det gäller att hålla sig på rätt sida av gränsen; steget från "besynnerlig” till "enbart konstig” är förmodligen inte särskilt långt.

Om nu slutet i ”Vad är det som säger att du inte redan älskar mig” är gåtfullt så kommer det inte an på mig att leverera svaret på gåtan. Det vore ju att stänga dörren. Jag tänker att det är skillnad på slut och avslut. Slutet på en novell behöver inte vara slutet på berättelsen, medan ett avslut är något mer definitivt - läsaren slår igen bokens pärmar för alltid, nöjd och bekräftad. Det öppna slutet (som inte är detsamma som att bara sluta) gör läsaren till en samarbetspartner. Alla svar finns i den enskilda läsningen av texten, som är skapad så. Precis som Richard Furumo värjer jag mig mot tanken på författaren som "utredare", eller någon som har fullständig kontroll över sina "stycken".

När jag funnit något vackert, så har jag antecknat det, utan att fråga, om det också tilläte en fullständig förklaring. Försöket att utreda har, när sådant egt rum, hos mig alltid blifvit det eftersta, och kan med skäl kallas eftertanke. Jag lemnar derhän huru bra det varit, men så har det varit. (Almqvist 1998: 172.)

Jag kan inte påstå att jag i efterhand brukar utforska det jag själv skriver. Men texter går alltid att tala om, om vi bortser från författaren och vad hen tänkte i själva 
skrivögonblicket. När det gäller "Vad är det som säger att du inte redan älskar mig” var det enkelt att ta klivet över till en läsarposition. Att just den här novellen kom att ingå i skrivuppgiften har med detta att göra: den har inte längre någon särskild laddning för mig personligen, den är ”desarmerad”. Därmed inte sagt att jag inte är helt utan beskyddarinstinkt! Det är självklart aldrig roligt att bli ifrågasatt för något man har skrivit, men i vissa lägen, när det skrivna inte riktigt har släppt den egna huden, blir det förstås extra smärtsamt.

I dialogen med herr Hugo reflekterar Richard Furumo över händelseutvecklingen i Drottningens juvelsmycke och Ramido Marinesco, men kommer inte med några definitiva svar. Det är en utmärkt hållning, som jag gärna övertar när vi återvänder till de två personerna i ”Vad är det som säger att du inte redan älskar mig”.

Det finns ett slags rå intimitet mellan de två personerna i köket. Ingen av dem, allra minst mannen, bär mask - om nu inte den totala patriarkala arrogansen är en mask, en mask som har stelnat och blivit ett med honom. Han lever ut denna arrogans, och här kan jag känna en gammal ilska poppa upp, över en viss manlig hänsynslöshet, tvånget att utifrån en viss måttstock "rätta till" den kvinna som för tillfället råkar befinna sig i hans närhet.

Kvinnan i novellen är lågmäld, en iakttagare. Ett kärl för mannens oförskämdheter. Inte bara oförskämdheter förresten, utan för allt han yttrar. Inledningsvis är han nästan trevlig. Kvinnan är varken det ena eller det andra. Hon gör sig inte till, och hon flirtar inte. Nej, hon är inte en person som flirtar, tänker jag. Hon framstår kanske som passiv, men det är hon som sitter på den verkliga makten, och hon demonstrerar den också, på sitt eget lilla sätt. Hämnas hon genom ”kärlek”?

Du och jag, tänkte hon prövande, du och jag. Varför inte? Vad är det som säger att du och jag inte kan komma att älska varandra? Vad är det som säger att du inte redan älskar mig?

Är inte detta ett hot mer än något annat?

I slutversionen av novellen lade jag till ett litet men betydelsefullt ord: ”Du och jag, din gris, tänkte hon prövande, du och jag.”

Jag vet inte om det är kärlek hon använder, eller gift. Kanske kom hon med kärlek, men lämnade kvar något helt annat. Min egen slutsats är att den på ytan vackre mannen i köket har ett förhärdat hjärta. I alla fall har han svårt att öppna det för den okända kvinna som plötsligt har klivit in i hans kök.

Mera:

Jag konstaterar att novellen utspelar sig på natten, i ett "efteråt”. Och vi vet ju att det som sägs och syns på natten är något annat än det som sägs och syns i dagsljus.

Jag tänker mig också: kärlek i teori och tanke, en slumpmässigt utvald person som objekt för detta. Kvinnan skannar av mannen i köket, tycks nöjd med det hon ser, men frågan är vad hon känner. Är hon inte mest ledsen? Varför skulle hon annars bli gråtfärdig av en hundvalp? 
Sedan kan jag inte låta bli att känna sorg över de hinder stereotypa könsroller ställer upp. Hur länge skulle mannen och kvinnan behöva sitta i köket för att nå fram till varandra på riktigt?

Om jag nu ska tycka något så tycker jag att slutet är det bästa med hela novellen. Det får berättelsen att vrida sig bort och ut -

Sedan då? Vad händer när sista punkten är satt? Jag lämnar med varm hand över till Richard Furumo att svara: "Läsaren kan utveckla denna tafla" (Almqvist 1998: 175).

Ramen finns ju där, och färgerna. Förmodligen går även motivet att ana. Men det viktiga är detta: det är inte avgjort.

Slut

Källor

Almqvist, C. J. L. (1998), Samlade Verk 7 (Törnrosens bok. Duodesupplagan. Band V-VII), utg. Bertil Romberg. Stockholm: Svenska Vitterhetssamfundet.

Bjelvehammar, B. (2015), ”Vardagens nära dramaturgi”, Tidningen Kulturen, 2015-09-01.

Bloom, H. (1973), The Anxiety of Influence: A Theory of Poetry. New York: Oxford University Press.

Davidsson, C. (1994), En av dessa nätter: Berättelser. Stockholm: Albert Bonniers Förlag.

Davidsson, C. (2008), "Vad är det som säger att du inte redan älskar mig”, Ordkonst, Nr 4, s. 13-16.

Davidsson, C. (2015), Höga berg, djupa dalar: Noveller. Stockholm: Albert Bonniers Förlag.

Falkenland, C. (2008), Vinterträdgården: Roman. Stockholm: Wahlström \& Widstrand.

Pettersson, M. (2015), ”Med blick för detaljerna”, Sydsvenskan, 2015-10-29.

Romberg, B. (1993), Carl Jonas Love Almqvist: Liv och verk. Stockholm: Ordfronts förlag. 
Höga berg, djupa dalar 


\section{Cecilia Davidsson}

Höga berg, djupa dalar

Noveller · Albert Bonniers Förlag 
Vad är det som säger

att du inte redan

älskar mig 





En Metro satt klämd i porten och tre våningar upp stod ett fönster på vid gavel, ut strömmade en låt av Tomas Ledin - blå, blå vindar och vatten - och även dörren till lägenheten var öppen, det var bara att kliva på, mitt i natten.

Vem vet, tänkte hon.

Hallen var tom - tömd - sånär på en matta som låg hoprullad mot ena väggen. På samma vägg hängde en tavla med en solnedgång i grälla färger. Lyssna till sommarnattens saing ... Hon fortsatte in i vardagsrummet där musiken hade sin källa, förväntade sig att få se det som möjligtvis blivit kvar av festen: ett par, stillsamt vaggande på golvet med huvudena tätt ihop, förenade i en kyss. Men inget sådant. Bara en rymlig herrsko strandad mitt på parketten. Låten tog slut och det kom ingen ny. I tystnaden som följde kunde hon uppfatta andra ljud och hon lät sig ledas av dem, inga röster, bara ljud från någon form av stillsam aktivitet, via en smal korridor som utmynnade i ett litet kök mot gården och där: en man med fingrarna i munnen.

Mannen hukade över en tallrik med överbliven plockmat. Fat och skålar belamrade diskbänken och köksbordet 
jämte skvättfyllda flaskor och kladdiga glas. På väggarna fler tavlor med nedåtgående solar som färgade himlarna overkligt röda.

»Hej«, sa hon.

Han höjde blicken, visade ingen förvåning, visade ingenting, medan han stoppade en salamiskiva i den redan välfyllda munnen. Han hade mörkt hår, bakåtstruket, och marinblå skjorta, finlemmade händer som blänkte av olja. Han tuggade mekaniskt med öppen mun medan han såg ut att begrunda något. Så sa han:

»En oliv, kanske? «

Ja, kanske, tänkte hon och satte sig på stolen mitt emot, snappade åt sig en oliv ur en avlång glasskål och sög in den mellan läpparna. Den kändes uppvärmd och var helt utan spänst.

I takt med att mannens intresse för henne ökade tuggade han allt långsammare.

»Vet du om att du är väldigt lik Tessy T? « sa han till slut.

Mycket hade hon fått höra, men inte just det.

»Väldigt lik faktiskt, trots att du är brunett. Tessy T är mycket ljusare. Ingen fullblodsblondin, men ljus.«

Han fyllde på med en blek och droppande kronärtskocka, torkade av munnen med handryggen.

»Samtidigt är ni som natt och dag. Ja, du förstår vad jag menar.«

»Nej, vad menar du? « sa hon och sträckte sig efter ett vinglas med rött grums i botten och fyllde det till hälften med vad som stod närmast: campari.

$\gg$ Du är ju inte hon menar jag, men med rätt styling skulle du kunna uppträda som hon och tjäna pengar på

98 
det. Som Elviskopiorna, det har ju blivit en industri i miljardklassen det där, och i ditt fall skulle det vara mer äkta eftersom ni lever båda två, du och Tessy T, medan Elvis är död sen länge och alla vet att kopiorna bara är kopior.«

Han gjorde en paus.

»Hon har väl inte dött nyligen, Tessy T?«

$\gg$ Inte vad jag vet $\ll$, sa hon.

$\gg N e j$, det är klart att hon lever. Om hon inte ligger och dör just nu, på nåt lyxhotell, det vet vi inget om. Men you bet att vi skulle få veta i morgon.«

»Antagligen.«

$\gg$ Om du var Tessy T skulle jag ... Ja, vad fan skulle man göra? Jag menar, tänk om man satt här mitt i natten och så plötsligt kommer hon in i köket ... Ett sånt läge får man inte sabba. Tro inte att jag är så dum att jag inte fattar att hon är människa hon med, hon både äter och skiter som vi andra, men visst är hon nåt mer än en ätande och skitande människa - en dröm, en jävligt sexig dröm.«

Hans blick irrade runt några sekunder någonstans mitt på henne.

»Ja du«, sa han sedan och petade ut något som fastnat i tänderna, något litet och rosafärgat, och knäppte i väg det med fingrarna.

$\gg$ Du skulle inte göra det du nyss gjorde om hon var här«, sa hon.

$\gg \mathrm{Va}$ ?

»Du skulle inte grisa dig.«

Han skrattade.

»Riktigt! Men nu är ju inte Tessy T här så jag grisar mig bäst fan jag vill.«

$\gg$ Och om hon var här?« 
》Ja, då skulle jag koppla på stora charmen ... Nä, sånt har hon säkert nog av: charmörer och rövslickare. Jag tror hon skulle uppskatta en helt vanlig hygglig kille som bjuder på en kopp te. Har du sett Notting Hill? «

»Men helst av allt skulle du vilja knulla henne.«

»Riktigt! Men en kopp te duger också. Vi snackar ju Tessy T.«

Han sköt undan tallriken, synade henne oförblommerat $i$ ansiktet.

»Alltså om du ... Nej.«

»Jo, säg.«

»Put a smile on your face. Det är allt jag vill säga.«

Hon skevade med munnen, och hon insåg att han verkligen trodde att hon försökte leverera ett riktigt leende.

$\gg$ Din stackare «, sa han.

Din stackare. Hon lät orden vältra runt i kroppen.

»Jag vet vad som kan få dig att le!«

Med ens så ivrig, på det där oövervinneliga sättet. Hon kände igen det. När hon var yngre hade det varit näst intill livsviktigt för dem att få henne att le. Genom smicker, en rolig historia, lite killkill i midjan, eller en ren order: Ge mig ett leende!

$»$ Du behöver inte ...«

Han reste sig upp och han var verkligen så lång som hon hade föreställt sig, säkert över en och nittio. Han fiskade upp en skrynklig servett från bordet och torkade av sig om händerna och försvann ut från köket. Vem vet, tänkte hon och tömde glaset med den rumsvarma camparin. Sekunden efter var den långe mannen tillbaka. Han hade något vitt och ulligt i famnen: en sovande hundvalp, inte större än hennes ena fot.

IOO 
»Pudeln Pär«, sa han och la valpen i hennes knä. Hon fångade upp den i händerna, kände hur varm den var.

»Söt, va?«

När valpen började gny fick hon lust att gråta.

»Du är ju för fan hopplös.«

»Jag tror att den gärna skulle vilja fortsätta sova.«

$\gg$ Du kan få den om du vill.«

»Jag är ingen hundmänniska.«

»Det kunde man ha gissat.«

Han lyfte upp valpen i nackskinnet och gick i väg. Kom visslande tillbaka, satte sig igen och studerade skålarna framför sig innan han bestämde sig för ytterligare en kronärtskocka.

»Vem är du, förresten? Vem känner du? « frågade han medan han tuggade.

»Anna, det var hon som tipsade mig.«

»Visst. Anna. Alla känner Anna.«

Du och jag, din gris, tänkte hon prövande, du och jag. Vad är det som säger att du och jag inte kan komma att älska varandra? Vad är det som säger att du inte redan älskar mig?

Han vred lite på sig, som för att bli kvitt ett obehag. Musklerna såg hårda ut under skjortan. Det stack upp lite svart hår vid kragen. Slät hals, perfekta öron.

»När du ser på mig så där ... Du påminner om nån.« $\gg$ Tessy T?

»Äh, jag fattar inte var jag fick det där ifrån.«

Han sträckte sig bakåt i stolen, tog sig om magen. Mättnaden verkade ha kommit som en obehaglig överraskning. $\gg$ Fy fan«, sa han och gäspade.

Hon stirrade in i hans blottade gap. Min älskade. Han 
avbröt sin gäspning, som om han plötsligt hade fått in en fluga i munnen. Han var verkligen mottaglig, men inte på det sätt hon önskade.

»Ska du inte gå hem nu«, sa han. »Festen är slut, om man säger så.«

»Jo, det ska jag«, sa hon.

$\gg$ Du kunde ju ha dykt upp tidigare «, sa han.

»Nej«, sa hon och reste sig från stolen och drog bort något som fastnat på undersidan av låret, en plastpåse.

God natt, min älskling.

$\gg$ Ciao«, sa hon.

Han brydde sig inte om att svara, nickade bara. Hade fullt upp med matsmältningen. Och hon som inte var Tessy T lämnade köket efter att ha stoppat ytterligare en oliv i munnen. Inte för att hon var sugen på en oliv utan för att ha något att göra med tungan. Hon blev stående i hallen. Såg sig omkring medan hon gnagde och sög olivkärnan ren från kött. Ingen spegel. Det var lite konstigt. Så spände hon läpparna och sköt ut kärnan rakt i solnedgången. Det small till.

»Aj! Vad fan sysslar du med!« ropade han från köket.

Hon gick fram till tavlan och studerade hålet, som kanske alltid varit där, hur skulle hon kunna veta, och stoppade dit pekfingret, borrade sig in. Han stönade högljutt. Försiktigt drog hon ut fingret. Hon hörde honom flämta, som efter en oväntad kraftansträngning. Hon såg nu att solen på tavlan snarare var på väg upp än ner, och i gryningsljuset blev allt så förtvivlat tydligt samtidigt som det fanns saker som bara försvann, suddades ut, och var mycket svåra, näst intill omöjliga, att i efterhand ens kunna föreställa sig. 